DOI : https://doi.org/10.24123/jbt.v4i2.2848

\title{
PENGARUH PENDAPATAN ASLI DAERAH (PAD), DAN DANA TRANSFER TERHADAP PENGALOKASIAN ANGGARAN BELANJA MODAL
}

\author{
Ade Onny Siagian \\ Dosen Akuntansi Universitas Bina Sarana Informatika, Jakarta \\ Email : ade.aoy@bsi.ac.id
}

\begin{abstract}
This study aimed to test the effect of Own Source Revenue and Fiscal Balance Transfer on Capital Expenditure Budget Allocation on Provincial Government on D.I Yogyakarta on 2012 to 2018 based on Statistic Indonesian (BPS).This research uses descriptive quantitative approach, which is measure using multiple linear regression based method use SPSS 24.0. The population of this study is the district / city in the D.I Yogyakarta in 2012 to 2018. The sample is determined based on the census method which is taking a sample of the total population that is as many as 35 samples. The data used in this study are secondary data, that colleted on official website www.djpk.kemenkeu.go.id. The analytical methods used are descriptive analysis, analysis of classic assumption and multiple linear regression analysis with level of significance is 5\%. Hypothesis testing is using regression partial test (t-Test) and the coefficient of determination test $\left(R^{2}\right)$.This result is Own Source Revenue and Fiscal Balance Transfer had a positive significant affect to Capital Expenditure Budget Allocation. This research is conducted 65,9\% of factors influencing Capital Expenditure Budget Allocation. Future research may use others independent variable.
\end{abstract}

Keyword : Own Source Revenue, Fiscal Balance Transfer, and Capital Expenditure Budget.

\section{Pendahuluan}

Dalam menciptakan suatu kemandirian daerah pemerintah daerah harus mampu mengelola sumber daya yang dimilikinya secara efisien dan efektif. Hal tersebut harus dapat diwujudkan dengan kebijakan desentralisasi melalui otonomi daerah. Mengatur dan mengurus urusan pemerintahan masyarakat setempat sesuai dengan peraturan yang berlakukan merupakan hak, wewenang dan kewajiban daerah otonomi dalam melaksanakan penerapan otonomi daerah. Otonomi daerah yang berlaku di Indonesia didasarkan pada UU No 22 Tahun 1999 yang telah direvisi menjadi UU No. 32 Tahun 2004. Undang-undang tersebut mengatur tentang Pemerintah Daerah dan Perimbangan Keuangan antara Pemerintah Pusat dan Pemerintah Daerah.

Pembangunan tersebut akan berdampak pada tingkat Pendapatan Asli Daerah(PAD) yang akan meningkatkan kemandirian pada daerah tersebut. Dalam upay meminimalkan kesenjangan (gap) antara tingkat layanan dengan harapan konsumen perlu dilakukan peningkatan kualitas dalam pelayanan publik dengan memperbaiki manajemen kualitas jasa (service quality management). Sehingga Pemerintah Daerah harus dapat melakukan pengalokasian anggaran belanja modal dengan baik karena belanja modal adalah salah 
satu langkah bagi Pemerintah Daerah untuk memberikan pelayanan kepala publik. Darwanto dan Yustikasari (2014) menyatakan bahwa pemanfaatan anggaran belanja seharusnya dialokasikan untuk hal - hal produktif, misalnya untuk pembangunan.

Penelitian ini mengacu pada penelitian yang dilakukan oleh Darwanto dan Yustikasari (2014). Variabel peneliatan yang digunakan dalam penelitian itu menggunakan variabel - variabel yang ada pada penelitian yang dilakukan oleh Darwanto dan Yustikasari (2014). Variabel - variabel yang digunakan diantaranya pertumbuhan ekonomi. Pendapatan Asli Daerah (PAD), dan Dana Alokasi Umum (DAU). Selain itu peneliti juga menambahkan variabel independen lain dalam penelitianya, yaitu Dana Alokasi Khusus (DAK). Karena pada penelitian yang dilakukan oleh Situngkir (2009) variabel tersebut berpengaruh signifikan terhadap belanja modal. Ada beberapa perbedaan dalam peneliatian ini jika dibandingkan dengan penelitian sebelumnya, dalam penelitian ini peneliti menambahkan variabel independen yang Dana Bagi Hasil (DBH). Peneliti menggunakan periode penelitian 2012-2018, karena dengan menggunakan data lima tahun terakhir dari penyusunan penelitian diharapkan dapata memberikan informasi yang relevan untuk kondisi belanja modal saat ini. Motivasi penelitian ini adalah untuk mengkonfirmasi penelitian Darwanto dan Yustikasari (2014) dan mengetahui apakah variabel Dana Bagi Hasil (DBH) berpengaruh positif terhadap pengalokasian anggaran belanja modal.

Berdasarkan pemaparan latar belakang yang telah dikemukakan sebelumnya,maka dapat dirumuskan beberapa permasalahan yang akan diteliti diantaranya: Berapa besar pengaruh Pendapatan Asli Daerah (PAD) terhadap alokasi anggaran belanja modal dan Berapa besar pengaruh Dana Transfer terhadap alokasi anggaran belanja modal.

\section{Tinjauan Pustaka}

Strategi dan Metode Penelitian

Menurut Rangkuti (2014 : 3) strategi adalah cara untuk mencapai suatu tujuan tertentu. Dalam perkembanganya, konsep mengenai strategi terus berkembang sedemikian rupa. Melalui adanya suatu strategi maka dapat dengan mudah melaksanakan tujuan - tujuan yang ingin dicapai melalui adanya suatu pendekatan. Maka pendekatan penelitian ini menggunakan pendekatan kuantitatif, menurut Kuncoro (2011) penelitian kuantitatif adalah penelitian yang dilakukan dengan data yang diukur dalam suatu skala secara numerik, hasil dalam penelitian ini menjelaskan mengenai gambaran suatu masalah penelitian dengan mengungkapkan hasil berdasarkan penjelasan angka - angka.

\section{Metode Penelitian}

Metode yang digunakan dalam penelitian ini menggunakan penelitian sosiatif yaitu penelitian yang bertujuan untuk mengetahui hubungan antara dua variabel atau lebih (Sugiyono, 2011), karena dalam penelitian ini akan dicari hubungan antara Pendapatan Asli Daerah (PAD), Dana Bagi Hasil (DBH), Dana Alokasi Umum (DAU), Dana Alokasi Khusus (DAK), antara variabel yaitu X1, X2, X3, dan X4 terhadap variabel yaitu Y (Alokasi Anggaran Belanja Modal).

1.1. Tahap Penelitian

1. Variabel Dependen.

Variabel dependen (variabel terikat) adalah variabel yang dipengaruhi, akibat dari adanya variabel bebas. Dikatakan sebagai variabel terikat karena variabel terikat dipengaruhi variabel independen. Dalam penelitian ini variabel dependen yang digunakan adalah belanja modal

Belanja Modal $=$ Belanja Tanah - Belanja Peralatan dan Mesin - Belanja Gedung dan Bangunan - Belanja Jalan, Irigasi, dan Jaringan - Belanja Aset Tetap Lainya. 
2. Variabel Independen

Variabel independen adalah variabel yang mempengaruhi atau sebab perubahan timbulnya variabel dependen. Variabel ini juga bisa dikatakan variabel bebas karena dapat mempengaruhi variabel lainnya. Variabel indepen yang digunakan dalam penelitian ini Pendapatan Asli Daerah (PAD), Dana Bagi Hasil (DBH), Dana Alokasi Umum (DAU), Dana Alokasi Khusus (DAK).

a. Variabel Pendapatan Asli Daerah

Pendapatan Asli Daerah menurut UU No. 33 Tahun 2004 adalah penerimaan yang diperoleh daerah dari sumber - sumber di dalam daerahnya sendiri yang dipungut berdasarkan peraturan daerah sesuai dengan peraturan perundang - undangan yang berlaku.. Variabel Pendapatan Asli Daerah diukur dengan rumus :

$\mathrm{PAD}=$ Pajak Daerah + Retribusi Daerah + Hasil Pengelolaan Kekayaan Daerah yang Dipisahkan + Lain - lain PAD yang Sah.

b. Variabel Dana Transfer

Dana Perimbangan merupakan sumber pendapatan daerah yang berasal dari APBN untuk mendukung pelaksanaan kewenangan pemerintah daerah dalam mencapai tujuan pemberian otonomi kepada daerah, yaitu terutama peningkatan pelayanan dan kesejahteraan masyarakat yang semakin baik (Widjaja, 2002).

Populasi dalam penelitian ini adalah seluruh pemerintah kota / kabupaten di Gunung Kidul dari tahun 2012 - 2018. Sampel yang digunakan dalam penelitian ini adalah pemerintah Propinsi D.I. Yogyakarta. Teknik penelitian ini menggunakan metode sensus. Metode sensus adalah metode dengan mengambil sampel seluruh kabupaten dan kota yang ada di Yogyakarta. Data sampel yang digunakan adalah kabupaten atau kota di Yogyakarta. Jenis data yang digunakan dalam penelitian ini adalah data sekunder. Sumber data dari dokumen laporan realisasi APBD yang diperoleh dari situs Dirjen Perimbangan Keuangan Pemerintah Daerah melalui website www.djpk.depkeu.go.id. Dan laporan realisasi APBD tahun 2012 - 2018, dapat diperoleh data mengenai jumlah pengalokasian anggaran Belanja Modal, Pendapatan Asli Daerah (PAD), Dana Transfer (perimbangan) dan Data diperoleh dari Badan Pusat Statistik (BPS). Metode pengumpulan data yang dilahirkan adalah metode dokumentasi dari sumber data sekunder dengan mengumpulkan, mencatat, dan mengolah data yang berkaitan dengan penelitian.

\section{Hasil Penelitian Dan Pembahasan}

Subjek dari penelitian ini adalah Kabupaten dan Kota di Provinsi D.I. Yogyakarta. Jumlah Kabupaten dan Kota di Provinsi D.I Yogyakarta sebanyak 5 Kabupaten dan Kota yaitu sebagai berikut : Kabupaten Bantul, Kabupaten Gunung Kidul, Kabupaten Kulon Progo, Kabupaten Sleman, Kota Yogyakarta. Data yang digunakan adalah data sekunder yaitu berupa dokumen laporan anggaran APBD yang diperoleh dari situs Dirjen Perimbangan Keuangan Pemerintah Daerah melalui website www.djpk.depkeu.go.id. Laporan anggaran APBD yang digunakan dari tahun 2012 sampai dengan 2018, sehingga diperoleh data mengenai jumlah anggaran Belanja Modal(BM), Pendapatan Asli Daerah(PAD), serta Data Transfer(DT) berdasarkan Badan Pusat Statistik (BPS). Jumlah sampel yang digunakan dalam penelitian ini sebanyak 35 sampel dengan metode pengumpulan data yang dilakukan adalah metode dokumentasi dari sumber data sekunder dengan mengumpulkan, mencatat, dan mengolah data yang berkaitan dengan penelitian. Penelitian ini berfokus pada tiga data yaitu Belanja Modal (Y), Pendapatan Asli Daerah (X1), dan Data Transfer (X2) untuk 
menguji pengaruh variabel bebas dengan variabel terikat, Berikut data khusus tentang Belanja Modal, Pendapatan Asli Daerah dan Dana Transfer pada laporan anggaran APBD Provinsi D.I Yogyakata :

\section{Tabel 1}

Data Anggaran APBD Belanja Modal, Pendapatan Asli Daerah, dan Dana Transfer Kabupaten/Kota di D.I. Yogyakarta

\begin{tabular}{|c|c|c|c|c|}
\hline Kabupaten/Kota & Tahun & l (Y) & $\begin{array}{l}\text { Pendapatan } \\
\text { Asli Daerah } \\
\text { (XI) }\end{array}$ & Dana Transfer (X2) \\
\hline Kab. Bantul & 2012 & $127,093,637,120.00$ & $121,593,864,192.00$ & $868,175,052,800.00$ \\
\hline Kab. Gunu & 2012 & $190,308,089,856.00$ & $55,600,361,472.00$ & $787,156,434,944.00$ \\
\hline Kab. Kulon Progo & 2012 & $138,686,251,008.00$ & $54,293,139,456.00$ & $605,036,412,928.00$ \\
\hline Kab. Sl & 2012 & $130,674,475,008.00$ & $220,367,224,832.00$ & $917,372,338,176.00$ \\
\hline Kota Yc & 2012 & $85,152,710,656.00$ & $241,190,748,160.00$ & $575,131,680,768.00$ \\
\hline Kab. Bantul & 2013 & $146,796,969,984.00$ & $170,006,167,552.00$ & $923,582,857,216.00$ \\
\hline Kab. Gunung & 2013 & $179,342,082,048.00$ & $66,710,859,776.00$ & $879,074,017,280.00$ \\
\hline Kab. Kulor & 2013 & $118,396,936,192.00$ & $64,750,333,952.00$ & $675,803,299,840.00$ \\
\hline Kab. Sleman & 2013 & $201,672,196,096.00$ & $298,406,936,576.00$ & $992,216,481,792.00$ \\
\hline Kota Yogy & 2013 & $121,557,114,880.00$ & $304,797,483,008.00$ & $656,301,031,424.00$ \\
\hline Kab. B & 2014 & $289,887,748,096.00$ & $265,128,263,680.00$ & $1,042,469,224,448.00$ \\
\hline Kab. Gunu & 2014 & $160,375,390,208.00$ & $90,333,151,232.00$ & $932,934,516,736.00$ \\
\hline Kab. Kulo & 2014 & $152,465,375,232.00$ & $92,815,163,392.00$ & $706,469,822,464.00$ \\
\hline Kab. & 2014 & $311,278,764,032.00$ & $383,497,895,936.00$ & $1,048,511,119,360.00$ \\
\hline Kota Yogy & 2014 & $269,821,345,792.00$ & $404,272,611,328.00$ & $685,422,870,528.00$ \\
\hline Kab. I & 2015 & $293,496,094,720.00$ & $312,419,909,632.00$ & $1,037,859,422,208.00$ \\
\hline Kab. Gunung Kidul & 2015 & $197,764,907,008.00$ & $145,856,397,312.00$ & $972,629,606,400.00$ \\
\hline Kab. Kulo & 2015 & $221,474,521,088.00$ & $187,802,910,720.00$ & $734,892,195,840.00$ \\
\hline Kab. Sleman & 2015 & $325,805,309,952.00$ & $564,060,946,432.00$ & $1,050,908,033,024.00$ \\
\hline Kota Yogyakarta & 2015 & $249,101,303,808.00$ & $449,849,098,240.00$ & $669,080,420,352.00$ \\
\hline Kab. B & 20 & $338,953,633,792.00$ & $349,492,805,632.00$ & $1,152,588,316,672.00$ \\
\hline
\end{tabular}




\begin{tabular}{|l|c|c|c|c|}
\hline Kab. Gunung Kidul & 2016 & $197,764,907,008.00$ & $145,856,397,312.00$ & $972,629,606,400.00$ \\
\hline Kab. Kulon Progo & 2016 & $307,589,283,840.00$ & $172,434,604,032.00$ & $1,062,502,072,320.00$ \\
\hline Kab. Sleman & 2016 & $348,203,024,384.00$ & $614,410,616,832.00$ & $1,456,154,738,688.00$ \\
\hline Kota Yogyakarta & 2016 & $313,355,763,712.00$ & $503,488,610,304.00$ & $967,286,325,248.00$ \\
\hline Kab. Bantul & 2017 & $315,617,788,885.00$ & $369,224,767,336.00$ & $1,435,225,759,712.00$ \\
\hline Kab. Gunung Kidul & 2017 & $340,666,979,023.00$ & $192,374,661,747.00$ & $1,356,665,458,114.00$ \\
\hline Kab. Kulon Progo & 2017 & $294,668,648,482.25$ & $221,215,012,961.59$ & $979,213,034,000.00$ \\
\hline Kab. Sleman & 2017 & $387,514,364,709.09$ & $698,754,166,932.00$ & $1,438,087,471,164.00$ \\
\hline Kota Yogyakarta & 2017 & $294,401,244,362.00$ & $511,132,838,058.00$ & $883,018,834,000.00$ \\
\hline Kab. Bantul & 2018 & $315,178,399,107.05$ & $420,143,106,639.00$ & $1,376,480,531,000.00$ \\
\hline Kab. Gunung Kidul & 2018 & $305,961,289,907.00$ & $208,747,851,213.37$ & $1,288,211,891,000.00$ \\
\hline Kab. Kulon Progo & 2018 & $362,984,344,169.00$ & $207,069,271,744.53$ & $993,976,585,000.00$ \\
\hline Kab. Sleman & 2018 & $364,638,098,154.00$ & $762,514,523,460.00$ & $1,411,867,128,000.00$ \\
\hline Kota Yogyakarta & 2018 & $263,212,904,954.00$ & $551,493,527,783.00$ & $912,713,788,000.00$ \\
\hline
\end{tabular}

Sumber : Data diolah peneliti (2018)

\section{Analisis Statistik Deskriptif}

Statistik deskriptif digunakan untuk memberikan gamabaran atau deskripsi suatu data yang dilihat dari rata - rata (mean), standar deviasi, variance, maksimum, minimum, kurtosis dan skewness atau kemencengan distribusi (Ghozali, 2001:16).

Berikut hasil dari uji statistik deskriptif dari data APBD 2012 - 2018 yang digunakan dalam penelitian ini:

Tabel 2.

\section{Hasil Uji Statistik Deskriptif}

\begin{tabular}{ll|l|l|l|l|l}
\multicolumn{1}{l}{} & & & & & \\
\cline { 5 - 6 } $\begin{array}{l}\text { Belanja } \\
\text { Modal }\end{array}$ & 35 & 85152710660.00 & 387514364700.00 & 247481768500.0000 & 86601441290.00000 \\
\hline $\begin{array}{l}\text { Pendapatan } \\
\text { Asli Daerah }\end{array}$ & 35 & 54293139460.00 & 762514523500.00 & 297774463700.0000 & 191000108900.00000 \\
\hline $\begin{array}{l}\text { Dana } \\
\text { Transfer }\end{array}$ & 35 & 575131680800.00 & 1456154739000.00 & 984218525100.0000 & 253286733100.00000 \\
\hline $\begin{array}{l}\text { Valid N } \\
\text { (listwise) }\end{array}$ & 35 & & & & \\
\hline
\end{tabular}

Sumber : Data diolah peneliti (2018) 
Berdasarkan tabel 2 menunjukan hasil pengukuran statistik deskriptif dari seluruh variabel dependen dan independen dengan jumlah populasi dalam penelitian ini adalah 35. Nilai rata - rata atau mean dari variabel dependen belanja modal yaitu Rp.247.481.768.500 dari nilai keseluruhan sampel. Sedangkan masing - masing variabel independen memiliki rata - rata yaitu pendapatan asli daerah sebesar Rp.297.774.463.700 dan dana transfer Rp. 984.218.525.100. Adapun penjelasan statistik deskriptif dari setiap variabel yaitu sebagai berikut :

a. Variabel Belanja Modal (Y)

Berdasarkan hasil pengolahan data dengan program IBM SPSS Statitic Version 24. Dengan jumlah populasi yang diteliti sejumlah 35. Variabel Belanja Modal memiliki nilai minimum yaitu sebesar Rp. 85.152.710.660 yang diperoleh dari Kota Yogyakarta tahun 2012 dan nilai maksimum diperoleh dari Kabupaten Sleman pada tahun 2017 yaitu sebesar Rp. 387.514.364.700.

Berdasarkan hasil pengolahan data dengan program IBM SPSS Statitic Version Dengan jumlah populasi yang diteliti sejumlah 35. Variabel Dana Transfer memiliki nilai minimum yaitu sebesar Rp. 575.131.680.800 yang diperoleh dari Kota Yogyakarta tahun 2012 dan nilai maksimum diperoleh dari Kabupaten Sleman pada tahun 2016 yaitu sebesar Rp 1.456.154.739.000.

Nilai dari standar deviasi yang didapat dari perhitungan statistik deskriptif yaitu sebesar Rp. 253.286.733.100. Standar deviasi digunakan untuk mengetahui bagaimana sebaran data dalam sampel dan seberapa dekat titik data responden terhadap nilai rata- rata atau mean.

\section{b. Variabel Dana Transfer (X2)}

Berdasarkan hasil pengolahan data dengan program IBM SPSS Statistics Version 24. Dengan jumlah populasi yang diteliti sejumlah 35. Variabel Dana Transfer memiliki nilai minimum yaitu sebesar Rp. 575.131.680.800 yang diperoleh dari Kota Yogyakarta tahun 2012 dan nilai maksimum diperoleh dari Kabupaten Sleman pada tahun 2016 yaitu sebesar Rp. 1.456.154.739.000.

Nilai dari standar deviasi yang didapat dari perhitungan statistik deskriptif yaitu sebesar Rp. 253.286.733.100.

Sebaliknya apabila nilai standar deviasi yang melebihi nilai rata-rata maka sebaran titik data tersebut akan menjauhi rata-ratanya.

3. Pengujian Hipotesis

a. Uji Asumsi Klasik

Uji asumsi klasik dilakukan sebelum analisis teknik regresi. Untuk mendapatkan model regresi yang baik harus terbebas dari penyimpangan data yang memiliki distribusi yang normal pada datanya, serta masalah multikolinearitas dan masalah heteroskedastisitas. Pengujian asumsi klasik yang dilakukan dalam penelitian ini yaitu uji normalitas, uji multikolinearitas, dan uji heteroskedastisitas.

b. Uji Normalitas

Uji normalitas bertujuan untuk menguji model regresi, variabel dependen maupun variabel independen memiliki distribusi normal atau tidak. Model regresi yang baik yaitu memiliki distribusi data yang normal ataupun mendekati normal. Uji normalistas dilakukan dengan menggunakan grafik histogram, P-Plot, dan uji Kolmogorov smirnov (Uji K-S). 


\section{Gambar 1.}

\section{Grafik Histogram Uji Normalitas}

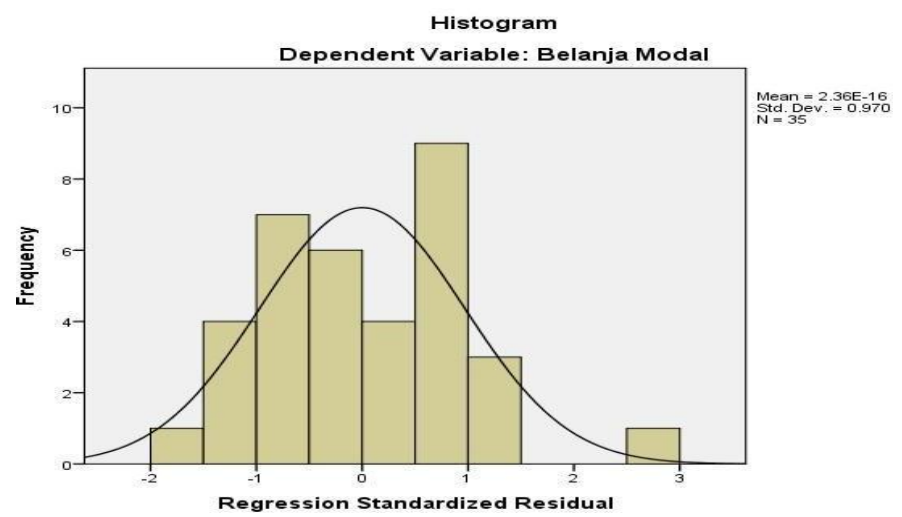

Sumber : Data diolah peneliti (2018)

Berikut grafik histogram pada gambar 1 dapat dilihat bahwa pola distribusi menunjukan normal (tidak memiliki kecenderungan ke kiri atau ke kanan) sehingga dapat disimpulkan bahwa model regresi memenuhi asumsi normalitas. Selain menggunakan histogram, uji penyebaran data dilakukan juga dengan grafik P-Plot.

Berdasarkan hasil uji SPSS menunjukan grafik P-Plot dengan distribusi titik titik data yang tersebar berada diantara garis diagonal, dan penyebaran titik - titik data mengikuti arah garis diagonal. Berdasarkan hal tersebut dapat diidentifikasikan bahwa grafik ini menunjukan model regresi yang layak karena memenuhi asumsi normalitas. Berikut grafik P-Plot hasil uji normalitas menggunakan SPSS Version 24:

\section{Gambar 2.}

\section{Grafik P - Plot Uji Normalitas}

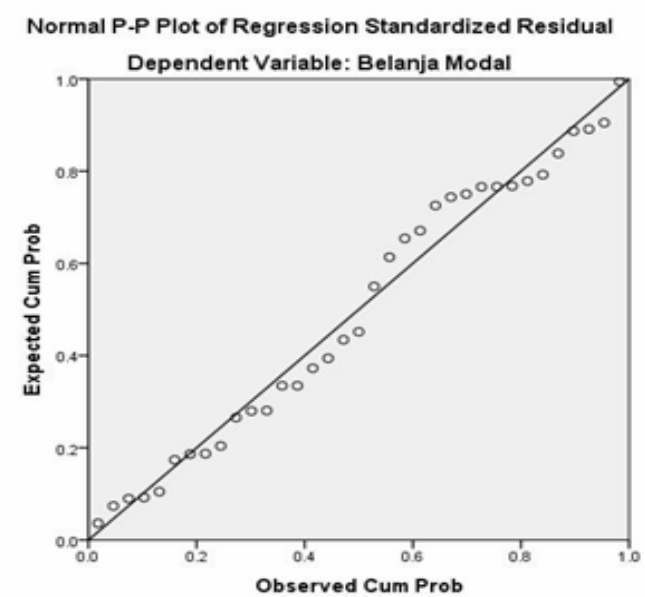

Uji normalitas yang dilakukan pada penelitiam ini selain melalui histogram dan P-Plot juga dilakukan secara statistik yaitu melalui uji Kolmogorov smirnov (Uji K-S). Data dikatakan memiliki distribusi normal atau tidakndapat dilihat dari nilai Asymp sig (2-tailed) yang didapatkan dari perhitungan sebagai berikut: 
Tabel 3.

Hasil UjI Kolmogorov - Smirnov

On sample kolmogorov - smirnov tes

Unstandardi

zed

Residual

\begin{tabular}{lll}
\hline & & 35 \\
\hline Normal Parameters $^{\mathrm{a}, \mathrm{b}}$ & Mean & .0000166 \\
\hline & Std. Deviation & 49027202210.00000000 \\
\hline Most Extreme Differences & Absolute & .103 \\
\cline { 2 - 3 } & Positive & .070 \\
\cline { 2 - 3 } & Negative & -.103 \\
\hline Test Statistic & & .103 \\
\hline Asymp. Sig. (2-tailed) & & $.200^{\mathrm{c}, \mathrm{d}}$ \\
\hline
\end{tabular}
a. Test distribution is Normal
b. Calculated from data
c. Liliefors Significance Correction
$d$. This is lower bound of the true significance

Sumber : Data diolah peneliti (2018)

Berdasarkan tabel 3 dapat diketahui bahwa nilai Asymp Sig (2-tailed) yaitu sebesar 0,200. Distribusi dikatakan normal jika nilai Asymp Sig (2-tailed) yang didapatkan lebih besar dari level of significant sebesar 5\% atau 0,05. Hal tersebut membuktikan bahwa data pada sampel yang digunakan pada penelitian ini memiliki distribusi nirmal.

a) Uji Multikolinearitas

Uji multikolonearitas bertujuan untuk menguji apakah model regresi ditemukan adanya korelasi antar variabel independen. Model regresi yang baik seharusnya tidak terjadi korelasi di antara variabel independen. Jika variabel independen saling berkorelasi, maka variabel tersebut tidak orthogonal.

Variabel orthogonal merupakan variabel independen yang nilai korelasi antar sesama variabel independenya sama dengan nol. Berikut hasil uji Multikolonieritas dengan SPSS 24: 
Tabel 4.

Hasil Uji Multikolonieritas Coefficients ${ }^{a}$

Collinearity

Statistics

\begin{tabular}{lll|l} 
Model & Tolerance & VIF \\
\hline \multirow{2}{*}{ Pendapatan Asli Daerah } & .745 & 1.342 \\
\cline { 2 - 3 } & & 1.342 \\
\hline
\end{tabular}

Dependen Variabel Belanja Modal

Sumber : diolah peneliti (2018)

Berdasarkan tabel 4 dapat diketahui bahwa variabel independen memiliki nilai tolerance lebih dari 0,10 dan nilai VIF kurang dari 10 (Ghozali, 2016:103). Variabel Pendapatan Asli Daerah memiliki nilai tolerance 0,745 dan VIF 1,342. Sedangkan Dana Transfer memiliki nilai tolerance 0,745 dan VIF 1,342.

Berdasarkan hasil pengujian dengan SPSS maka diketahui bahwa nilai tolerance dan VIF yang didapatkan lebih besar dari nilai ketetapan. Jadi berdasarkan perhitungan tersebut dapat disimpulkan bahwa tidak ada multikolonieritas antar variabel independen dalam model regresi.

b) Uji Heterokedastisitas

Uji Heteroskedastisitas bertujuan untuk menguji apakah dalam sebuah model regresi terjadi ketidaksamaan varians dari residual satu pengamatan dengan pengamatan lain.

Tabel 5.

Hasil Uji Heterokedastisitas

Coefficients $^{\mathbf{a}}$

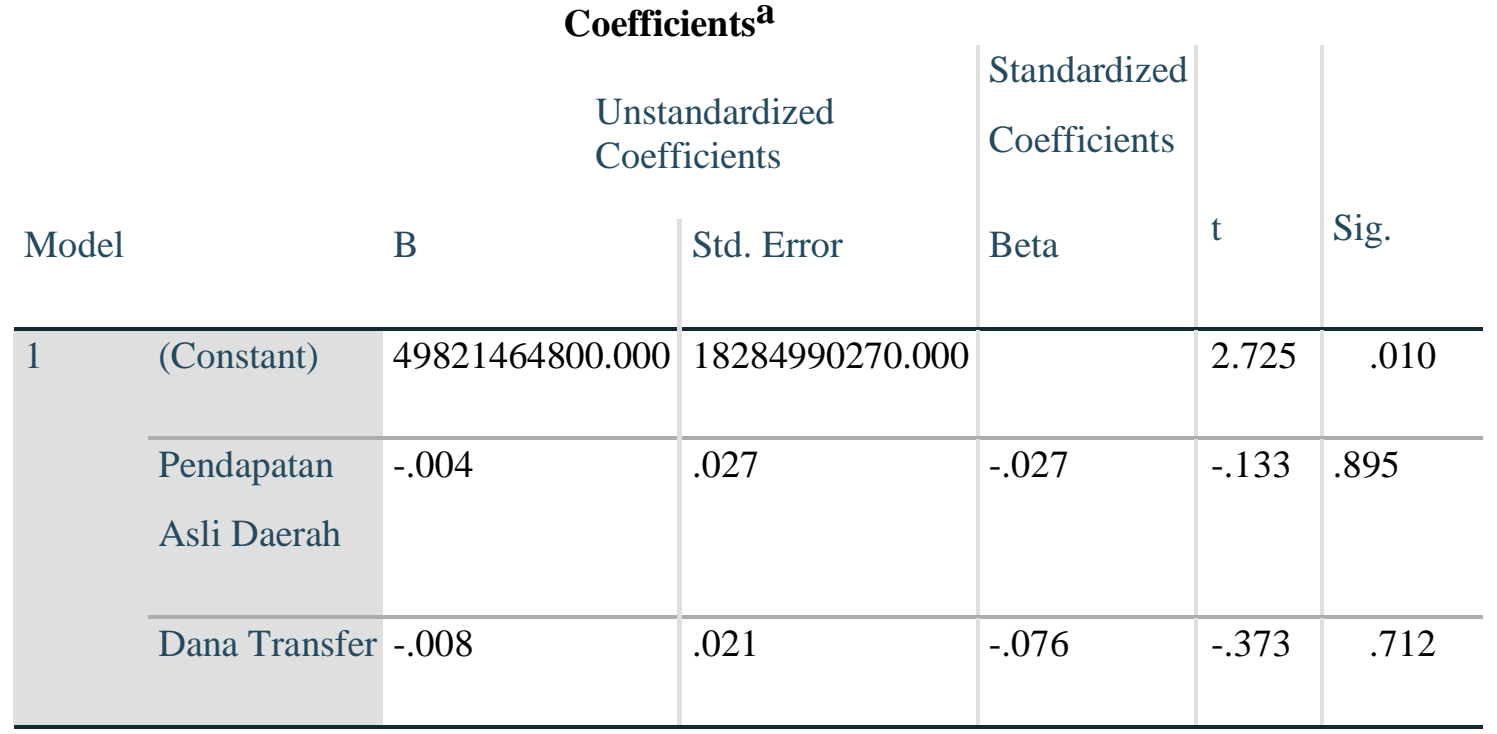

Variabel dependen absolute

Sumber : Data diolah peneliti (2018) 
Berdasarkan tabel 5 menunjukan hasil uji heterokedastisitas dari masing - masing variabel independen yaitu pendapatan asli daerah sebesar 0,895 dan dana transfer sebesar 0,712 . Nilai probabilitas yang dimiliki oleh masing-masing variabel independen berada diatas 0,05 atau $5 \%$, jadi dapat disimpulkan bahwa data yang digunakan terbebas dari heterokedastisitas.

Adapun uji heterokedastisitas dalam penelitian ini bukan hanya dengan uji Glejser, namun juga dideteksi menggunakan grafik scatterpot. Berdasarkan gambar 3 yang menunjukan grafik Scatterplot menunjukan bahwa titik-titik data terdistribusi atau tersebar secara acak. Titik-titik data tersebut tidak membentuk suatu pola serta tidak cenderung berkumpul di atas maupun di bawah. Berdasarkan hal tersebut dapat disimpulkan bahwa tidak terjadi heteroskedetisitas pada model regresi, sehingga model regresi layak digunakan.

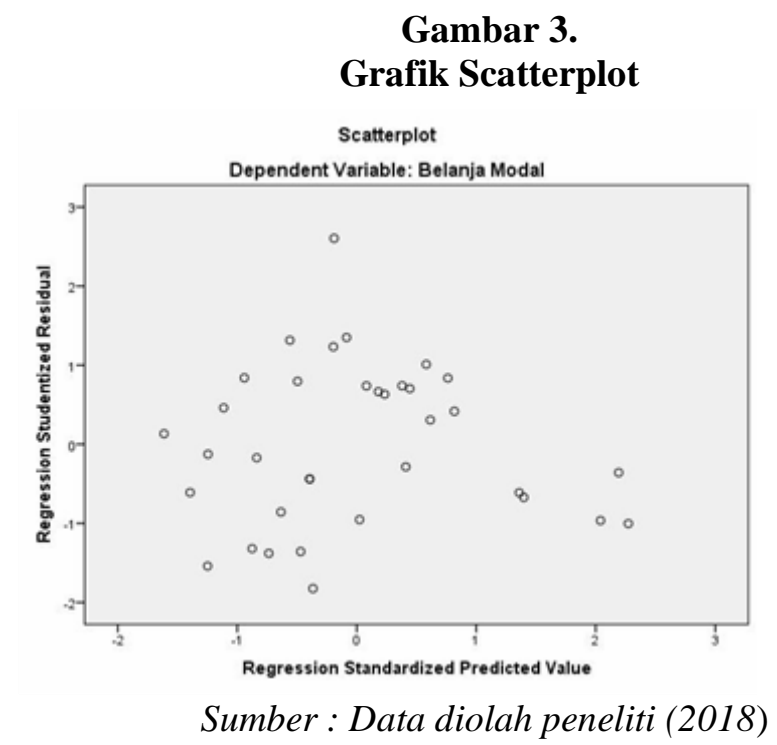

c) Uji Autokorelasi

Uji autokorekasi bertujuan menguji apakah dalam model regresi linier ada korelasi antara kesalahan pengganggu pada periode $t$ dengan kesalahan penggangu pada periode t-1 (sebelumnya). Jika terjadi korelasi maka dinamakan ada problem autokorelasi. Model regresi yang baik adalah regresi yang bebas dari autokorelasi. Salah satu cara yang digunakan untuk mendeteksi ada atau tidaknya autokorelasi adalah dengan Uji Durbin Watson.

Tabel 6.

Hasil Uji Autokorelasi Durbin Waston Model Summaryb

\begin{tabular}{|c|c|c|c|c|c|}
\hline Model & $\mathrm{R}$ & R Square & $\begin{array}{l}\text { Adjusted } \mathrm{R} \\
\text { Square }\end{array}$ & $\begin{array}{l}\text { Std. Error of the } \\
\text { Estimate }\end{array}$ & $\begin{array}{l}\text { Durbin- } \\
\text { Watson }\end{array}$ \\
\hline 1 & $.824^{\mathrm{a}}$ & .680 & 659 & 50536083310.00000 & 1.842 \\
\hline
\end{tabular}

Predictors : (Constant), Dana Transfer, Pendapatan Asli Daerah Dependent Variable :

Belanja Modal

Sumber : Data diolah oleh peneliti (2018) 
Berdasarkan tabel Durbin Watson dengan variabel bebas sebanyak 2 variabel $(\mathrm{k}=$ 2) dan jumlah data $35(\mathrm{n}=35)$ maka didapatkan nilai $\mathrm{dl}=1,343$ dan $\mathrm{du}=1,584$. Berdasarkan perhitungan SPSS nilai DW sebesar 1,842 lebih besar dari batas atas (du) 1,584 dan kurang dari $4-1,584(4-\mathrm{du})$, maka dapat disimpulkan bahwa tidak ada autokorelasi positif atau negatif sehingga model regresi yang digunakan terbebas dari autokorelasi $(\mathrm{du}<\mathrm{d}<4-\mathrm{du})$.

Adapun pengujian autokorelasi juga dilakukan dengan uji run (run test). Run test sebagai bagian dari statistic non-parametik yang dapat digunakan untuk menguji apakah antar residual terdapat korelasi yang tinggi. Jika antar residual tidak terdapat hubungan korelasi maka dapat dikatakan bahwa residual adalah acak atau random. Berikut hasil run test pada SPSS 24:

Tabel 7.

\section{Hasil Uji Autokorelasi Run Test}

Unstandardized Residual

\begin{tabular}{ll}
\hline Test Value & -6150811563.00000 \\
\hline Cases $<$ Test Value & 17 \\
\hline Cases $>=$ Test Value & 18 \\
\hline Total Cases & 35 \\
\hline Number of Runs & 19 \\
\hline Z & .005 \\
\hline Asymp. Sig. (2-tailed) & .996 \\
\hline
\end{tabular}

Median

Sumber : Data diolah peneliti (2018)

Hasil output SPSS menunjukkan bahwa nilai test adalah -6.150.811.563 dengan probabilitas 0,996 signifikansi pada 0,05 yang berarti dapat disimpulkan bahwa residual menyebar secara random dan tidak terjadi autokorelasi antar nilai residual.

\section{Regresi Linier Berganda}

Setelah seluruh variabel dalam penelitian ini terbebas dari masalah uji asumsi klasik, selanjutnya dapat dilakukan analisi regresi berganda. Regresi berganda berguna untuk melihat apakah spesikfikasi model yang digunakan sudah benar atau tidak. Analisis ini bertujuan untuk mengetahui bagaimana variabel independen mempengaruhi variabel dependen. Pada penelitian ini digunakan variabel independen yaitu Pendapatan Asli Daerah dan Data Transfer sedangkan variabel dependen yaitu Belanja Modal. Berikut hasil pengujian regresi berganda: 
Tabel 8.

Hasil Uji Regresi Linier Berganda Coefficients ${ }^{a}$

\begin{tabular}{|c|c|c|c|c|c|}
\hline & \multicolumn{2}{|c|}{ Unstandardized Coefficients } & \multirow{2}{*}{$\begin{array}{l}\text { Standardized } \\
\text { Coefficients } \\
\text { Beta }\end{array}$} & \multirow{2}{*}{ t } & \multirow[b]{2}{*}{ Sig. } \\
\hline Model & B & Std. Error & & & \\
\hline 1 (Constant) & 5538233851.000 & 34979106120.000 & & .158 & .875 \\
\hline $\begin{array}{l}\text { Pendapatan Asli } \\
\text { Daerah }\end{array}$ & .170 & .053 & .376 & 3.239 & .003 \\
\hline Dana Transfer & .194 & .040 & .568 & 4.902 & .000 \\
\hline
\end{tabular}

Dependen Variabel Belanja Modal

Sumber : Data diolah peneliti (2018)

Berdasarkan tabel 8 yaitu hasil uji analisis regresi linear berganda, maka diperoleh persamaan regresi sebagai berikut: $\mathbf{B M}=\mathbf{5 . 5 3 8 . 2 3 3 . 8 5 1}+\mathbf{0 , 1 7 0}$ PAD + 0,194 DT + e

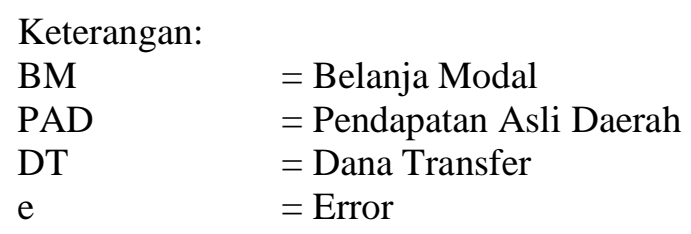

Berdasarkan dari persamaan regresi berganda tersebut, maka diberikan penjelasan sebagai berikut:

a. Nilai konstanta diketahui memiliki nilai sebesar 5.538.233.851 artinya jika semua variabel independen bernilai 0 atau konstan, maka nilai Belanja Modal akan meningkat sebesar 5.538.233.851 kali.

b. Variabel Pendapatan Asli Daerah (X1) memiliki nilai koefisien sebesar 0,170.

5. Variabel Dana Transfer memiliki nilai koefisien sebesar 0,194. Koefisien positif menunjukkan bahwa variabel Dana Transfer memiliki hubungan yang searah dengan Belanja Modal. Uji Hipotesis

- $\quad$ Uji Koefisien Determinasi $\left(\mathrm{Uji}^{2}\right)$

Uji $\mathrm{R}^{2}$ digunakan untuk mengetahui seberapa besar kontribusi variabel independen terhadap variabel dependen. Besar koefisien determinasi $\left(\mathrm{R}^{2}\right)$ mengukur seberapa jauh kemampuan model dalam menerangkan variasi variabel dependen. Adapun variabel independen dalam penelitian ini adalah pendapatan asli daerah (X1) dan dana transfer (X2) serta variabel dependen yaitu belanja modal (Y). 
Tabel 9.

Hasil Uji Koefisien Determinasi Model Summary

\begin{tabular}{ll|l|l|l|l} 
& & & & \\
Model & R Square & Square & Estimate & Watson \\
\hline 1 & $.824^{\mathrm{a}}$ & .680 & .659 & 50536083310.00000 & 1.842
\end{tabular}

Predictors : (Contant), Dana Transfer, Pendapatan Asli Daerah Dependent variable belanja modal

Sumber : Data diolah peneliti (2018)

Berdasarkan tabel 9 menunjukan hasil uji koefisiensi determinasi dan menghasilkan nilai adjusted $\mathrm{R}^{2}$ sebesar 0,659. Penggunaan Adjusted $\mathrm{R}^{2}$ karena variabel independen yang digunakan lebih dari satu, jadi perlu di rata-ratakan. Uji Regresi Simultan (Uji F)

Uji F dilakukan untuk menunjukan apakah semua variabel bebas yang dimaksud dalam model mempunyai pengaruh signifikan terhadap variabel dependen. Uji $F$ jugA dimaksudkan untuk mempengaruhi apakah variabel bebas memiliki koefisien regresi sama dengan nol.

Tabel 10.

\section{Hasil Uji Regresi Simultan ANOVA ${ }^{a}$}

\begin{tabular}{|c|c|c|c|c|c|}
\hline Model & Sum of Squares & df & Mean Square & $\mathrm{F}$ & Sig. \\
\hline 1 Regression & $\begin{array}{l}17326886460000000000000 \\
\text { n0.000 }\end{array}$ & 2 & $\begin{array}{l}86634432310000000000000.0 \\
00\end{array}$ & 33.922 & $.000^{\mathrm{b}}$ \\
\hline Residual & $\begin{array}{l}81724662920000000000000 \\
.000\end{array}$ & 32 & 2553895716000000000000.00 & 35.922 & .000 \\
\hline Total & $\begin{array}{l}25499352750000000000000 \\
0.000\end{array}$ & 34 & & & \\
\hline
\end{tabular}

Dependent Variable Belanja Modal Predictors : (Contant), Dana Transfer, Pendapatan Asli Daerah

Sumber : Data diolah peneliti (2018)

Untuk menentukan nilai F-tabel dapat menggunakan rumus df (n-k-1) dimana $\mathrm{k}=2$ yang merupakan jumlah variabel independen, dan $\mathrm{n}=35$ yang merupakan jumlah sampel. Maka dengan tingkat signifikansi 5\% dan degree of freedom (df) $=32$ diperoleh nilai $\mathrm{F}$ tabel sebesar 4,12. Atau bisa digunaka rumus pada Microsoft excel yaitu $=\mathrm{FINV}(0.05,1,35)$. 
Berdasarkan tabel IV.9 diketahui bahwa F-hitung yaitu sebesar 33,922 dimana hal ini berarti bahwa F-hitung yang diperoleh lebih besar dari F-tabel.

Berdasarkan hasil uji tersebut mempresentasikan bahwa variabel independen yaitu pendapatan asli daerah dan dana transfer secara simultan berpengaruh terhadap variabel dependen yaitu belanja modal. Dengan kata lain, dapat dikatakan bahwa model penelitian ini layak untuk diteliti dan pembuktian hipotesis dapat dilakukan.

- Uji Parsial (Uji t)

1) Uji t digunakan untuk mengetahui apakah variabel-variabel independen secara parsial berpengaruh nyata atau tidak terhadap variabel dependen. Derajat signifikansi yang digunakan adalah 0,05. Selain itu, uji t dapat pula dilakukan dengan membandingkan nilai t-tabel dengan nilai t-hitung.

2) Untuk menentukan nilai t-tabel maka didapat menggunakkan rumus df (n-k-1) dimana nilai df sebesar 32 yang didapat dari (35-2-1), dimana n sebesar 35 adalah jumlah sampel dan $\mathrm{k}$ sebesar 2 adalah jumlah variabel independen dalam penelitian ini. Dengan nilai df 32 dan signifikansi 0,050, maka diperoleh nilai t-tabel adalah sebesar 2,04. Adapun bisa menggunakan bantuan Microsoft excel rumus $=\operatorname{TINV}(0.05,32)$. Berikut hasil pengujian parsial dalam penelitian ini:

Tabel 11.

Hasil Uji Parsial

Coefficients $^{\mathbf{a}}$

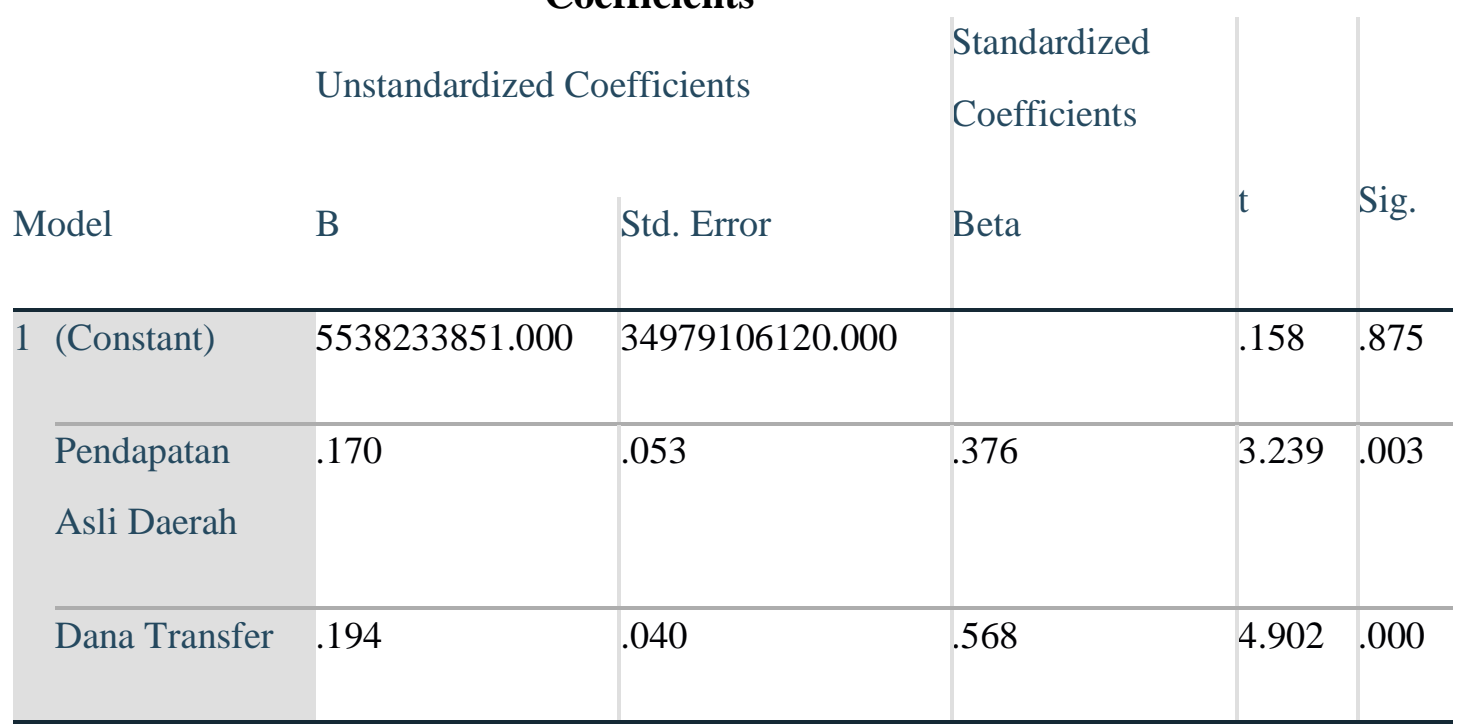

Sumber : Data diolah peneliti (2018)

Dependen Variable : Belanja Modal

Berdasarkan hasil dari data yang diolah maka didapatkan kesimpulan berikut :

3) H1 : Pendapatan Asli Daerah berpengaruh terhadap Belanja Modal

Berdasarkan tabel IV.10 dapat diketahui bahwa variabel pendapatan asli daerah memiliki nilai signifikansi lebih kecil dari 0,05 yaitu sebesar 0,003 dan memiliki nilai thitung lebih besar dari t-tabel $(2,04)$ yaitu sebesar 3,239. Dengan demikian maka H1 diterima dan $\mathrm{H} 0$ ditolak, sehingga menunjukan bahwa pendapatan asli daerah (X1) berpengaruh positif dan signifikan terhadap belanja modal (Y). 
4) H2 : Dana Transfer berpengaruh terhadap Belanja Modal

Berdasarkan tabel IV.10 dapat diketahui bahwa variabel dana transfer memiliki nilai signifikansi lebih kecil dari 0,05 yaitu sebesar 0,000 dan memiliki nilai t-hitung lebih besar dari t-tabel $(2,04)$ yaitu sebesar 4,902. Dengan demikian maka H2 diterima dan H0 ditolak, sehingga menunjukan bahwa dana transfer (X2) berpengaruh positif dan signifikan terhadap belanja modal (Y).

a) Pengaruh Pendapatan Asli Daerah terhadap Pengalokasian Anggaran Belanja Modal

Berdasarkan hasil dari analisis regresi berganda pada tabel IV. 7 menunjukan bahwa pendapatan asli daerah memiliki nilai signifikansi yang lebih kecil dari 0,05 yaitu sebesar 0,003 (sig < 5\%), dengan nilai t-hitung sebesar 3,239 yang berarti lebih besar dari $\mathrm{t}$-tabel sebesar 2,04 (t-hitung > t-tabel). Hal tersebut membuktikan bahwa pengajuan hipotesis diterima yaitu pendapatan asli daerah berpengaruh positif dan signifiikan terhadap belanja modal. Hasil ini menunjukkan bahwa semakin tinggi pendapatan asli daerah maka belanja modal akan semakin meningkat, begitu juga sebaliknya apabila semakin rendah pendapatan asli daerah maka belanja modal akan semakin rendah.

Hasil penelitian ini mendukung penelitian yang dilakukan oleh Sumarni (2009) yang menyatakan bahwa pendapatan asli daerah berpengaruh positif dan signifikan terhadap belanja modal. Hal ini disebabkan karena pendapatan asli daerah merupakan sumber pendapatan yang didapatkan dari daerah yang digunakan untuk membiayai penyelenggaraan kegiatan pemerintahan dan pembangunan daerah tersebut.. Penelitian ini juga sejalan dengan penelitian Ernayani (2017), Situngkir dan Manurung (2015), Arif (2015) yang menyatakan bahwa pendapatan asli daerah berpengaruh positif dan signifikan terhadap belanja modal.

b) Pengaruh Dana Transfer terhadap Pengalokasian Anggaran Belanja Modal Dalam penelitian ini dana transfer didefinisikan sebagai dana yang bersumber dari pendapatan APBN yang dialokasikan kepada pemerintah daerah untuk mendanai kebutuhan daerahnya dalam rangka pelaksanaan desentralisasi fiskal.

Berdasarkan hasil dari analisis regresi berganda pada tabel 7 menunjukan bahwa pendapatan asli daerah memiliki nilai signifikansi yang lebih kecil dari 0,05 yaitu sebesar 0,000 (sig < 5\%) dengan nilai t-hitung sebesar 4,902 yang berarti lebih besar dari t-tabel sebesar 2,04 (t-hitung > t-tabel).

\section{Simpulan}

Pendapatan asli daerah memiliki pengaruh positif dan signifikan terhadap pengalokasian belanja modal. Hal ini mengindikasikan bahwa anggaran belanja modal pada D.I Yogyakarya yang digunakan untuk membiayai penyelenggaraan kegiatan pemerintahan dan pembangunan daerah tersebut dipengaruhi oleh pendapatan asli daerah yang merupakan sumber pendapatan yang didapatkan dari D.I Yogyakarta. Dana Transfer memiliki pengatuh positif dan signifikan terhadap pengalokasian belanja modal di D. I Yogyakarta. Hal ini menunjukan bahwa belanja modal dimanfaatkan dalam usaha pemerintah guna membiayai pembangunan dan usaha-usaha daerah yang masih ketergantungan dengan dana pemerintah pusat, dimana besaran belanja modal dipengaruhi oleh dana transfer.

\section{Saran}

Bagi pemerintah daerah Propinsi D.I.Yogyakarta semua pendapatan yang diperoleh pemerintah daerah baik yang berasal dari DP ataupun PAD harus dapat digunakan dengan tepat sasaran sehingga dapat menjamin kesejahteraan masyarakatnya. Variabel yang digunakan dalam penelitian akan datang diharapkan lebih lengkap dengan 
menambah variabel independen lain baik dari jenis penerimaan daerah lainnya.

\section{Daftar Pustaka}

Abdullah, S., \& Halim, A. (2012). Pengaruh Dana Alokasi Umum (DAU) dan Pendapatan Asli Daerah (PAD) terhadap Belanja Pemerintah Daerah: Studi Kasus Kabupaten/ Kota di Jawa dan Bali. Proceeding Simposium Nasional Akuntansi VI. Surabaya.

Adyatma, Erdi dan Oktaviani, Rachmawati Meita. (2014). Pengaruh Penghasilan real dan Dana Alokasi Umum terhadap Belanja Modal dengan Pertumbuhan Ekonomi pada periode tahun 2011-2013. EaJournals Vol. 2 No. 6.

Aprizay, Yudi Satrya, Darwanis, Muhammad Arfan, (2014). Pengaruh Pendapatan Asli Daerah, Dana Perimbangan dan Sisa Lebih Pembiayaan Anggaran Terhadap Pengalokasian Belanja Modal Pada Kabupaten/ Kota di Provinsi Aceh. Jurnal Akuntansi Fakultas Ekonomi Univeritas Syiah Kuala. Banda Aceh.

Ardhani, Pungky. (2011). Pengaruh Pertumbuhan Ekonomi, Pendapatan Asli Daerah, Dana Alokasi Umum, Dan Dana Alokasi Khusus Terhadap Pengalokasian Anggaran Belanja Modal (Studi Pada Pemerintah Kabupaten/Kota Di Jawa Tengah). Skripsi. Universitas Diponegoro. Semarang.

Bruns, H. J. (2014). HR development in local government: how and why does HR strategy matter in organizational change and development?. Business Research, 7(1), 1-49.

Darwanto dan Yutikasari, Yulia. (2007). Pengaruh Pertumbuhan Ekonomi, Pendapatan Asli Daerah dan Dana Perimbangan terhadap pengalokasian Anggaran Belanja Modal pada kabupaten/kota di Pulau Jawa dan Bali. SNA X. Unhas Makasar.

Departemen Keuangan Republik Indonesia Direktorat Jenderal Perimbangan Keuangan, Laporan APBD. www.djpk.depkeu.go.id.

Direktorat Jenderal Perimbangan Keuangan. (2013). Deskripsi dan Analisis APBD 2013.Kementerian Keuangan RI. Jakarta.

Efferin, Sujoko and Darmadji, Stevanus Hadi and Tan, Yuliawati (2008) Metode Penelitian Akuntansi; Mengungkap Fenomena dengan Pendekatan Kuantitatif dan Kualitatif. Graha Ilrnu, Yogyakarta. ISBN 978-979-756-342-4

Efferin, S., Darmadji, S. H., \& Tan, Y. (2004). Metode penelitian untuk akuntansi. Malang: Bayumedia Publishing.

Ernayani, R. (2017). Pengaruh Pendapatan Asli Daerah, Dana Alokasi Umum, Dana Alokasi Khusus dan Dana Bagi Hasil terhadap Belanja Daerah (Studi Kasus pada 14 Kabupaten/Kota di Provinsi Kalimantan Timur Periode 2009-2013). JSHP (Jurnal Sosial Humaniora dan Pendidikan), 1(1), 43-52.

Giri, E. F. (2012). Akuntansi Keuangan Menengah 1. Yogyakarta: Upp Stim Ykpn.

Ghozali, Imam, 2013. Aplikasi Analisis Multivariate Dengan Program SPSS. Edisi Ketujuh, Badan Penerbit Universitas Diponegoro, Semarang.

Hartono J. \&Sulistiawan, D. (2014) "The Market Quality to Technical Analysis Performance: Inter Country Analysis," Gadjah Mada International Journal of Business (forthcoming)

Hariyanto, David dan Adi Priyo Hadi. (2007). Hubungan Antara Dana Alokasi Umum, Belanja Modal Pendapatan Asli Daerah Dan Pandapatan Perkapita. Simposium Nasional Akuntansi X. Makassar.

Hamzah, Ardi. (2009). Pengaruh Pendapatan Asli Daerah, Dana Perimbangan dan Belanja Publik terhadap Pertumbuhan Ekonomi, Kemiskinan, dan Pengangguran : Pendekatan Analisis Jalur. (Studi Pada 38 Kota/Kabupaten di Propinsi Jawa Timur Periode 2001-2006). Jurnal Balitbang Depdagri.

Kawedar, Warsito, dkk. (2008). Akuntansi Sektor Publik (Pendekatan Penganggaran 
Daerah dan Akuntansi Keuangan Daerah/Buku 1. Semarang: Salemba Empat.

Maimunah, Mutiara. (2006). Flypaper Effect pada Dana Alokasi Umum (DAU) dan Pendapatan Asli Daerah (PAD) terhadap Belanja Daerah Pada Kabupaten/Kota Di Pulau Sumatra. Simposium Nasional Akuntansi IX. Padang.

Mawarni; Darwanis; Syukriy Abdullah. (2013). Pendapatan Asli Daerah (PAD), Dana Alokasi Umum (DAU) terhadap belanja modal serta dampaknya terhadap pertumbuhan ekonomi daerah kabupaten/kota di Provinsi Aceh. Jurnal Akuntansi vol 2, no 2.

Metghalchi, M., Chang, Y., \& Gomez, X.G. (2012), "Technical analysis of the Taiwanese Stock Market," International Journal of Economics and Finance, vol 4 (1), p. 90-102.

Saleh R, Siagian AO, (2020), "Sponsorship dalam Menciptakan Sikap Merek", Jurnal Bisnis Terapan 4 (1), 13-22.

Setiyawati, Hamzah .(2015). Pengaruh Pendapatan Daerah dan Dana Perimbangan terhadap Belanja Modal kabupaten/kota di Jawa Barat Tahun 2010-2014. Jurnal Akuntansi dan keuangan, vol 4, no 2.

Siagian AO, N Indra, (2019), "Pengetahuan Akuntansi Pelaku Usaha Mikro Kecil dan Menengah (UMKM) Terhadap Laporan Keuangan", Syntax Literate; Jurnal Ilmiah Indonesia 4 (12), 17-35 vol: 4.

Siagian AO, (2019), "Pengaruh Daya Tarik Iklan Dan Penempatan Produk Terhadap Kesadaran Merek Grab di Acara Indonesian Idol 2018”, Jurnal Pemasaran Kompetitif, 118-130.

Siagian AO, (2020), "Pengaruh Dana Pihak Ketiga, Modal Bank, Jumlah Kantor Cabang, Tingkat Suku Bunga dan Jumlah Uang Beredar Terhadap Jumlah Kredit UMKM Bank BUMN", Syntax Literate; Jurnal Ilmiah Indonesia

Siagian AO, (2020), "Contribution of Inventory Accounting Systems in Improving Inventory Internal Control", Journal of Sosial Science 1 (2), 1-6.

Siagian AO, (2020), "Keterkaitan Individualitas Manajerial Pemasaran Dalam Menghadapi Revolusi Industri 4.0 Terutama Pada Perusahaan Manufaktur Di Jawa Tengah”, Syntax Literate; Jurnal Ilmiah Indonesia 5 (10), 980-994.

Situngkir, Anggiat dan John Sihar Manurung. (2015). Efek Memiliki Pendapatan Daerah, Pengalokasian Dana Umum dan Dana Khusus pada Belanja Modal di Kota dan Kabupaten Sumatera Utara. Kajian Akuntansi, Vol 4, no 2: 93 - 103 ISSN 1907- 1442.

Sholikhah, Imroatus dan Wahyudin, Agus. (2014). Pengaruh Pertumbuhan Ekonomi, Pendapatan Asli Daerah, dan Dana Alokasi Khusus terhadap Pengalokasian Anggaran Belanja Modal. Sampel yang digunakan yaitu Kabupaten / Kota di Jawa dan Bali Tahun 2011-2013. Accounting Analysis Journal, vol 3, no 4. 
